\title{
Dose optimization study for recombinant tissue plasminogen activator in acute ischemic stroke: A study from Middle-East
}

\author{
${ }^{1}$ Helia Hemasian $M D,{ }^{2}$ Erfan Sheikhbahaei $M D,{ }^{2}$ Arvin Shahzamani ${ }_{M D}$, ${ }^{1}$ Faribourz \\ Khorvash $M D,{ }^{1}$ Mohammad Saadatnia $M D,{ }^{2}$ Zahra Rastinmaram \\ ${ }^{1}$ Department of Neurology, Alzahra University Hospital; ${ }^{2}$ Student Research Committee, School of \\ Medicine, Isfahan University of Medical Sciences, Isfahan, Iran
}

\begin{abstract}
Background: Variable intravenous recombinant tissue-plasminogen activator (rt-PA) dosages are used for ischemic stroke. We aimed to report our experience from administering different rt-PA doses in a tertiary referral center in Middle-East. Method: Medical documents of ischemic stroke patients who received rt-PA were retrospectively reviewed and analyzed. Patients were grouped into three categories based on the received total amount of rt-PA and their body weight: $0.6 \mathrm{mg} / \mathrm{kg}$ (low-dose), $0.75 \mathrm{mg} / \mathrm{kg}$ (intermediate-dose), and $0.9 \mathrm{mg} / \mathrm{kg}$ (high-dose). During the hospitalization period, patients were under full surveillance for rt-PA complications. The validated format of the National Institutes of Health stroke scale (NIHSS) and the modified Rankin scale (mRS) were used at the baseline, at the time of being discharged, and after 3 months. Chi-square, ANOVA, and ANCOVA were used for statistical analysis. Results: 602 patients were evaluated and grouped as follow: 187 (31.06\%) in 0.6 $\mathrm{mg} / \mathrm{kg}$ group (61\% male) with mean age of $68 \pm 15$ years, $217(36.04 \%)$ in $0.75 \mathrm{mg} / \mathrm{kg}$ group $(59 \%$ male) with mean age of $67 \pm 13$ years, and $198(32.89 \%)$ in $0.9 \mathrm{mg} / \mathrm{kg}$ group (50\% male) with mean age of $69 \pm 17$ years. There was no significant difference between the three groups regarding their demographics, comorbidities, and the distribution of stroke risk factors. No significant difference was seen between the three groups regarding in-hospital death and intracranial hemorrhage $(p=0.07$ and 0.09 , respectively). In terms of NIHSS, no significant difference was observed between the three groups at the time of admission, discharge, and follow-up ( $\mathrm{p}=0.98,0.85$, and 0.47 , respectively). At the time of discharge, the $\mathrm{mRS}$ of $0.6 \mathrm{mg} / \mathrm{kg}$ group was significantly higher than the other two groups $(\mathrm{p}=0.04)$, which decreased in the 3-month follow-up and did not make significant differences $(\mathrm{p}=0.38)$. Conclusions: According to the in-hospital mortality, intracranial hemorrhage, mRS, and NIHSS scores, we recommend $0.75 \mathrm{mg} / \mathrm{kg}$ as our safe, beneficial, and cost-effective dosage.
\end{abstract}

Keywords: stroke; tissue plasminogen activator; mortality; intracranial hemorrhage

\section{INTRODUCTION}

Cerebral vascular attack (CVA) or stroke is one of the leading causes of mortality and morbidity worldwide. ${ }^{1-3}$ Administering intravenous recombinant tissue-plasminogen activator (rt-PA) as the mainstay of ischemic stroke management can decrease the severity and extension of brain injury and lower the impairment level in the future if injected rapidly to appropriate patients. ${ }^{3-6}$ Variable rt-PA dosages are used without any reliable or established evidence. The European and American neurologists have recommended 0.9 milligrams per kilogram of body weight $(\mathrm{mg} / \mathrm{kg})$ of rt-PA even though it may cause intracerebral hemorrhage (ICH) in some patients..$^{4-8}$ The studies from Asian populations have shown that a lower dose of rt-PA, from $0.6-0.9 \mathrm{mg} / \mathrm{kg}$, is equally effective and safe..$^{9-15}$ Therefore, a universal dose cannot be administered to every patient, and the appropriate rt-PA dosage should be found in any nation to have a balanced riskbenefit outcome. ${ }^{4,5,14-20,6-13}$

No study has ever reported the appropriate rtPA dose from the Middle-East region. Therefore, in this study, we aimed to report our experience from administering different rt-PA doses to the

Address correspondence to: Arvin Shahzamani M.D. Student Research Committee, School of Medicine, Isfahan University of Medical Sciences, Hezar jarib Blvd. Azadi Sq. Isfahan, Iran. Tel: +989133235343, Email: Arvin.shahzamani@yahoo.com

Date of Submission: 8 March 2021; Date of Acceptance: 8 May 2021

https://doi.org/10.54029/2021jfx 
Iranian population for the first time.

\section{METHODS}

For this retrospective study, medical documents of patients with ischemic stroke who were referred to our referral university-affiliated hospital were retrieved from 2016 to 2020 . Inclusion criteria for this study were patients older than 18 years old with ischemic stroke in brain computed tomography (CT), had rt-PA indications and received rt-PA within 270 minutes from starting their symptoms. ${ }^{3-5}$

Stroke was suspected in any patients who were admitted to the emergency room due to focal neurologic deficit (e.g., signs of lateralization, dysarthria, disequilibrium, and visual disturbance). Hemorrhagic stroke was ruled-out with brain CT; therefore, they were evaluated for receiving rt-PA based on current stroke guidelines. ${ }^{3-5}$ The only provided rt-PA for this hospital was Actilyse ${ }^{\circledR}$ (50 $\mathrm{mg}$ alteplase from Boehringer Ingelheim Pharmaceutical Company). There is no consensus on rt-PA dosage neither in the world nor in the Iranian population. Therefore, based on the expert neurologists' opinion of this study, demographics, and comorbidities of patients, different doses of rt-PA were administered to have a rounded number and fewer unconsumed drugs according to costeffectiveness protocols. Patients were grouped based on their body weight and total administered rt-PA dose as follow: $0.6 \mathrm{mg} / \mathrm{kg}$ (low-dose), 0.75 $\mathrm{mg} / \mathrm{kg}$ (intermediate-dose), and $0.9 \mathrm{mg} / \mathrm{kg}$ (highdose).

By assuming alpha (type 1 error) of 0.05 , beta (type 2 error) of $0.2, \mathrm{~d}=0.05$, and mean ICH incidence of $14 \%$ according to our previous experiences, an approximate total number of 600 patients was calculated to be sufficient for this study.

\section{Assessments}

A checklist containing age, gender, body weight, comorbidities (i.e. type 2 diabetes mellitus, hypertension, hyperlipidemia, atrial fibrillation (AF)), smoking and drinking alcohol, previous stroke and transient ischemic attack (TIA), history of hospitalization for a heart problem, medication list (including anticoagulant), and the onset of symptoms were filled before administering the rt-PA. During the hospitalization period, patients were under full surveillance for rtPA complications (e.g. ICH, cardiorespiratory arrest, new neurological deficit). For evaluating the level of improvement, the validated format of the National Institutes of Health stroke scale (NIHSS) ${ }^{21}$ and the modified Rankin scale (mRS) were used at the entrance, time of being discharged, and after 3 months. The first MRS considered the level of disability before the onset of CVA. NIHSS has 11 domains with final scores ranging from 0 to 25 . nRS ranges from 0 to 6 according to the clinical condition of the patient.

\section{Statistical analysis}

Data imported to IBM SPSS software version 20.0 for statistical analysis. Data were stratified by the dosage of administered rt-PA (0.6, 0.75, and $0.9 \mathrm{mg} / \mathrm{kg}$ ). Numerical and categorical data were presented as mean \pm standard deviation (SD) and frequency (percentage). The normality of numerical data was evaluated using the Kolmogorov-Smirnov test. ANOVA and Chisquare tests were used to compare each numerical and categorical variable between three groups of rt-PA doses, respectively. Post Hoc analysis and Bonferroni's correction were used where needed. The repeated measure method was used to compare different time points within a group. Analysis of covariance (ANCOVA) was used for comparing continuous variables in each group when adjustment was made for age, sex, and weight. The $\mathrm{p}$-value (2-tailed) of $<0.05$ was considered statistically significant.

\section{RESULTS}

Six hundred and two patients with signs and symptoms of stroke were referred to our hospital from 2016 to 2020 and were rt-PA candidates after evaluating their CTS. They were grouped in three categories based on their body weight and total received Actilyse ${ }^{\circledR}: 187$ (31.06\%) in 0.6 $\mathrm{mg} / \mathrm{kg}$ group, $217(36.04 \%)$ in $0.75 \mathrm{mg} / \mathrm{kg}$ and $198(32.89 \%)$ in $0.9 \mathrm{mg} / \mathrm{kg}$ group. The baseline characteristics and comorbidities are listed in Table 1. There was no significant difference between the three groups regarding the distribution of stroke risk factors ( $>00.05)$.

In-hospital death was higher in Group 1, ICH and 3-month mortality were higher in Group 2, and Group 3 had a more extended hospitalization period; however, none of them was significant (Table 2).

The average NIHSS and MRS scores are presented in Table 3. At the time of admission, no significant difference was observed between the three groups in terms of NIHSS score $(\mathrm{p}=0.98)$. There was no significant difference during discharge $(\mathrm{p}=0.85)$ and at the follow-up 
Table 1: Demographic data and comorbidities of included patients in each rt-PA group

\begin{tabular}{|c|c|c|c|c|}
\hline Variable & $\begin{array}{c}\text { Group } 1 \\
0.6 \mathrm{mg} / \mathrm{kg} \\
(\mathrm{n}=187)\end{array}$ & $\begin{array}{c}\text { Group } 2 \\
0.75 \mathrm{mg} / \mathrm{kg} \\
(\mathrm{n}=217)\end{array}$ & $\begin{array}{c}\text { Group } 3 \\
0.9 \mathrm{mg} / \mathrm{kg} \\
(\mathrm{n}=198)\end{array}$ & $\mathbf{P}$ \\
\hline Age (years) & $68.38 \pm 15.26$ & $67.08 \pm 13.39$ & $69.20 \pm 17.41$ & 0.91 \\
\hline Male sex $n,(\%)$ & $115(61.49)$ & $128(58.98)$ & $99(50)$ & 0.23 \\
\hline Weight (kg) & $85.53 \pm 9.66$ & $89.98 \pm 4.57$ & $87.08 \pm 10.26$ & 0.79 \\
\hline Diabetes Mellitus, n (\%) & $59(31.55)$ & $55(25.34)$ & $47(23.73)$ & 0.54 \\
\hline Hypertension, n (\%) & $105(56.14)$ & $137(63.13)$ & $101(51.01)$ & 0.39 \\
\hline Drinking and/or Smoking, n (\%) & $25(13.36)$ & $28(12.9)$ & $31(15.65)$ & 0.87 \\
\hline Atrial Fibrillation, n (\%) & $12(6.41)$ & $15(6.91)$ & $23(11.61)$ & 0.45 \\
\hline History of stroke, n (\%) & $18(9.62)$ & $24(11.05)$ & $15(7.57)$ & 0.39 \\
\hline Dyslipidemia, n (\%) & $33(17.64)$ & 39 (17.97) & $35(17.67)$ & 0.78 \\
\hline Ischemic Heart Disease, n (\%) & $22(11.76)$ & $27(12.44)$ & $29(14.64)$ & 0.11 \\
\hline
\end{tabular}

time $(\mathrm{p}=0.47)$. MRS score before CVA was not significantly different between the three groups $(p=0.22)$. At the time of discharge, the mRS score was significantly higher than the other two groups $(\mathrm{p}=0.04)$ in Group 1, which decreased in the 3-month follow-up and did not make significant differences $(\mathrm{p}=0.38)$. Repeated measure analysis revealed a significant difference between baseline and subsequent study time-points in every group, and these differences remained significant after adjustment with the ANCOVA model (Table 3).

\section{DISCUSSION}

The most important findings of this study are that no significant difference was found between our three rt-PA groups regarding the rate of $\mathrm{ICH}$ and NIHSS score. However, according to the mRS score, dosages $>0.6 \mathrm{mg} / \mathrm{kg}$ were better than the $0.6 \mathrm{mg} / \mathrm{kg}$ itself at the discharging time.
Whenever rt-PA is indicated, it should be administered to prevent further damages in the brain in cases of ischemic strokes. ${ }^{3-6}$ The appropriate rt-PA dose is dependent on two principle rules: the least chance of complication with the most significant functional improvement. Different researches from different countries have recommended various doses between 0.6-0.9 mg/kg of rt-PA. ${ }^{4,5,14-20,6-13}$ However, there is no unanimous consensus on the appropriate dose. ${ }^{4,5,14-20,6-13}$ No study has ever evaluated the Middle-East region in which stroke is prevalent and recognized as one of the most important morbidities and mortality factors. ${ }^{1}$

American and European researchers recommended $0.9 \mathrm{mg} / \mathrm{kg}$ of $\mathrm{rt}-\mathrm{PA}$ as their safe and effective dose. ${ }^{3,7}$ Nevertheless, Diedler et al. indicated that patients with body weight $>100 \mathrm{~kg}$ who received $0.9 \mathrm{mg} / \mathrm{kg}$ of $\mathrm{rt}-\mathrm{PA}$ were more in

Table 2: The rate of rt-PA complications during hospital admission

\begin{tabular}{|c|c|c|c|c|}
\hline Variable & $\begin{array}{c}\text { Group } 1 \\
0.6 \text { mg/kg } \\
(n=187)\end{array}$ & $\begin{array}{c}\text { Group } 2 \\
0.75 \mathrm{mg} / \mathrm{kg} \\
(\mathrm{n}=217)\end{array}$ & $\begin{array}{c}\text { Group } 3 \\
0.9 \text { mg/kg } \\
(n=198)\end{array}$ & $\mathbf{P}$ \\
\hline $\begin{array}{l}\text { Hospitalization period } \\
\text { (days) }\end{array}$ & $7.21 \pm 5.94$ & $6.54 \pm 9.27$ & $8.72 \pm 10.03$ & 0.63 \\
\hline $\begin{array}{l}\text { Intra-cranial hemorrahge } \\
\text { n }(\%)\end{array}$ & $18(9.62)$ & $22(10.13)$ & $19(9.59)$ & 0.09 \\
\hline $\begin{array}{l}\text { In-hospital death } \\
\text { n }(\%)\end{array}$ & 19 (10.16) & $15(6.91)$ & $17(8.58)$ & 0.07 \\
\hline $\begin{array}{l}\text { 3-month death } \\
\text { n }(\%)^{*}\end{array}$ & $8(4.76)$ & $11(5.44)$ & $9(4.97)$ & 0.88 \\
\hline
\end{tabular}

*Percentages are after subtracting the in-hospital deaths from total numbers. 
Table 3: NIHSS and MRS scores in each rt-PA group at each timeline

\begin{tabular}{|c|c|c|c|c|c|c|}
\hline Questionnaire & Timing & $\begin{array}{c}\text { Group } 1 \\
0.6 \text { mg/kg } \\
(n=187)\end{array}$ & $\begin{array}{c}\text { Group } 2 \\
0.75 \mathrm{mg} / \mathrm{kg} \\
(\mathrm{n}=217)\end{array}$ & $\begin{array}{c}\text { Group } 3 \\
0.9 \text { mg/kg } \\
(n=198)\end{array}$ & $\begin{array}{c}\mathbf{P} \\
\text { (Unadjusted) }^{*}\end{array}$ & $\frac{\mathbf{P}}{(\text { Adjusted })^{\dagger}}$ \\
\hline \multirow{5}{*}{ NIHSS } & Entrance $(n=602)$ & $10.89 \pm 6.01$ & $10.88 \pm 3.94$ & $10.45 \pm 4.11$ & 0.98 & 0.81 \\
\hline & Discharge $(n=551)$ & $7.16 \pm 7.18$ & $7.33 \pm 6.58$ & $6.28 \pm 5.21$ & 0.85 & 0.53 \\
\hline & 3-month later $(n=523)$ & $5.88 \pm 5.76$ & $4.55 \pm 3.82$ & $4.47 \pm 3.91$ & 0.47 & 0.79 \\
\hline & $\mathbf{P}(\text { Unadjusted })^{\ddagger}$ & $<0.0001$ & $<0.0001$ & $<0.0001$ & - & - \\
\hline & $\mathbf{P}(\text { Adjusted })^{\dagger}$ & 0.001 & 0.01 & 0.003 & - & - \\
\hline \multirow{5}{*}{ MRS } & Before Stroke $(n=602)$ & $1.25 \pm 1.82$ & $0.91 \pm 1.25$ & $0.63 \pm 1.37$ & 0.22 & 0.66 \\
\hline & Discharge $(\mathrm{n}=551)$ & $2.41 \pm 1.69$ & $1.49 \pm 1.33$ & $1.67 \pm 1.65$ & 0.04 & 0.85 \\
\hline & 3-month later $(n=523)$ & $2.27 \pm 1.94$ & $1.69 \pm 1.46$ & $1.94 \pm 1.83$ & 0.38 & 0.92 \\
\hline & $\mathbf{P}(\text { Unadjusted })^{\ddagger}$ & 0.02 & 0.04 & $<0.0001$ & - & - \\
\hline & $\mathbf{P}(\text { Adjusted })^{\dagger}$ & 0.01 & 0.04 & 0.01 & - & - \\
\hline
\end{tabular}

MRS: modified Rankin scale, NIHSS: National Institutes of Health stroke scale

* This p-value was calculated with ANOVA

$\dagger$ Adjustment was made for age, sex, and weight with ANCOVA model

$\$$ This p-value was calculated with repeated measure method

danger of ICH than the patient who received lesser doses with the same bodyweight range. .,22 $^{8}$ According to our findings, although ICH was not significantly different between the three rt-PA groups, it was higher in the $0.75 \mathrm{mg} / \mathrm{kg}$ group. The literature lacks sufficient evidence from Middle-East; however, prior researches from Asia demonstrated different results. In contrast to our findings, ICH in $0.8-0.9 \mathrm{mg} / \mathrm{kg}$ of $\mathrm{rt}-\mathrm{PA}$ was higher than $0.7-0.8 \mathrm{mg} / \mathrm{kg}$ from India's study. However, the functional improvement was better in lower doses. In South Korea and Japan, 0.6 $\mathrm{mg} / \mathrm{kg}$ is recommended as the safe and effective dose $\mathrm{e}^{10,11,13,15,23}$ alteplase at $0.6 \mathrm{mg} / \mathrm{kg}$ was approved in October 2005 for use within 3 hours of stroke onset by the Ministry of Health, Labor and Welfare (MHLW; however, Chinese researchers suggested that $0.9 \mathrm{mg} / \mathrm{kg}$ is their best shot regarding the lower ICH and better functional improvement. ${ }^{20} \mathrm{~A}$ randomized clinical trial in this subject had 63.2\% of patients of Asian ethnicity. ${ }^{7}$ Their comparison between 0.6 and $0.9 \mathrm{mg} / \mathrm{kg}$ of rt-PA revealed that functional improvement was not significantly different between the two groups although the ICH was lower in $0.6 \mathrm{mg} / \mathrm{kg}$ as predicted. ${ }^{7}$ Their findings are in line with other studies from Japan in which it was shown that 0.6 and $0.9 \mathrm{mg} / \mathrm{kg}$ of rt-PA were not significantly different according to functional improvement. ${ }^{15}$

This study's limitations were its retrospective design, using documents of one referral universityaffiliated center, lack of randomization and blinding, and loss of long-term follow-up. We recommend multi-centric randomized clinical trials between different dosages of rt-PA with longer follow-up evaluations for future researches.

In conclusion, according to the in-hospital mortality and $\mathrm{ICH}$, all three dosages were the same. Regarding the mRS score at the time of discharging and functional improvement, 0.75 and $0.9 \mathrm{mg} / \mathrm{kg}$ of rt-PA was better than $0.6 \mathrm{mg} /$ $\mathrm{kg}$; however, no superiority was observed when increasing the rt-PA dosage from 0.75 to $0.9 \mathrm{mg} /$ $\mathrm{kg}$. Therefore, we recommend $0.75 \mathrm{mg} / \mathrm{kg}$ as our safe, beneficial, and cost-effective dosage.

\section{ACKNOWLEDGEMENT}

The authors express their gratitude toward $\mathrm{Mr}$. Amirsalar Moazen Safaei for his kind support during the project.

\section{DISCLOSURE}

Financial support: None

Conflicts of interest: None

Ethics approval: This study is approved by the Isfahan University of Medical Sciences' institutional review board with the registration number of "IR.MUI.MED.REC.1397.293".

Availability of data and material: The data is available for secondary analysis in necessary cases from the corresponding author through an email address. 


\section{REFERENCES}

1. Ghandehari K. Epidemiology of stroke in Iran. Galen Med J 2016;5(Supp.1):3-9.

2. Ovbiagele B, Nguyen-Huynh MN. Stroke epidemiology: Advancing our understanding of disease mechanism and therapy. Neurotherapeutics 2011;8(3):319-29.

3. Powers WJ, Derdeyn CP, Biller J, et al. 2015 American Heart Association/American stroke association focused update of the 2013 guidelines for the early management of patients with acute ischemic stroke regarding endovascular treatment: A guideline for healthcare professionals from the American . Stroke 2015;46(10):3020-35.

4. Demaerschalk BM, Kleindorfer DO, Adeoye OM, et al. Scientific rationale for the inclusion and exclusion criteria for intravenous alteplase in acute ischemic stroke. A statement for healthcare professionals from the American Heart Association/American Stroke Association. Stroke 2016; 47:581-641.

5. De Keyser J, Gdovinová Z, Uyttenboogaart M, Vroomen PC, Luijckx GJ. Intravenous alteplase for stroke: Beyond the guidelines and in particular clinical situations. Stroke 2007;38(9):2612-8.

6. Albers GW, Bates VE, Clark WM, Bell R, Verro P, Hamilton SA. Intravenous tissue-type plasminogen activator for treatment of acute stroke: The standard treatment with alteplase to reverse stroke (STARS) study. J Am Med Assoc 2000;283(9):1145-50.

7. Anderson CS, Robinson T, Lindley RI, et al.Low-dose versus standard-dose intravenous alteplase in acute ischemic stroke. N Engl J Med 2016;374(24):231323.

8. Diedler $\mathrm{J}$, Ahmed $\mathrm{N}$, Glahn $\mathrm{J}$, et al. Is the maximum dose of $90 \mathrm{mg}$ alteplase sufficient for patients with ischemic stroke weighing $>100 \mathrm{~kg}$ ? Stroke 2011;42(6):1615-20.

9. Zhou XY, Wang SS, Collins ML, Davis SM, Yan B. Efficacy and safety of different doses of intravenous tissue plasminogen activator in Chinese patients with ischemic stroke. J Clin Neurosci 2010;17(8):988-92.

10. Yamaguchi T, Mori E, Minematsu K, et al. Alteplase at $0.6 \mathrm{mg} / \mathrm{kg}$ for acute ischemic stroke within 3 hours of onset: Japan Alteplase Clinical Trial (J-ACT). Stroke 2006;37(7):1810-5.

11. Sharma VK, Ng KWP, Venketasubramanian N, et al. Current status of intravenous thrombolysis for acute ischemic stroke in Asia. Int J Stroke 2011;6(6):52330.

12. Rha JH, Shrivastava VP, Wang Y, et al. Thrombolysis for acute ischaemic stroke with alteplase in an Asian population: Results of the multicenter, multinational Safe Implementation of Thrombolysis in Stroke-NonEuropean Union World (SITS-NEW). Int J Stroke 2014;9(A100):93-101.

13. Nakagawara J, Minematsu $\mathrm{K}$, Okada $\mathrm{Y}$, et al. Thrombolysis with $0.6 \mathrm{mg} / \mathrm{kg}$ intravenous alteplase for acute ischemic stroke in routine clinical practice: The Japan post-Marketing Alteplase Registration Study (J-MARS). Stroke 2010;41(9):1984-9.

14. Ramaiah SS, Yan B. Low-dose tissue plasminogen activator and standard-dose tissue plasminogen activator in acute ischemic stroke in asian populations:
A review. Cerebrovasc Dis 2013;36(3):161-6.

15. Toyoda K, Koga M, Naganuma M, et al. Routine use of intravenous low-dose recombinant tissue plasminogen activator in japanese patients: General outcomes and prognostic factors from the SAMURAI register. Stroke 2009;40(11):3591-5.

16. Chao AC, Hsu HY, Chung CP, et al. Outcomes of thrombolytic therapy for acute ischemic stroke in Chinese patients: The Taiwan thrombolytic therapy for acute ischemic stroke (TTT-AIS) study. Stroke 2010;41(5):885-90.

17. Hacke W, Kaste M, Fieschi C, et al. Randomised double-blind placebo-controlled trial of thrombolytic therapy with intravenous alteplase in acute ischaemic stroke (ECASS II). Lancet 1998;352(9136): 1245-51.

18. Hill MD, Buchan AM. Thrombolysis for acute ischemic stroke: Results of the Canadian Alteplase for Stroke Effectiveness Study. CMAJ 2005;172(10):1307-12.

19. Kim BJ, Han MK, Park TH, et al. Low-versus standard-dose alteplase for ischemic strokes within 4.5 hours: A comparative effectiveness and safety study. Stroke 2015;46(9):2541-8.

20. Wang Y, Liao X, Wang Y, et al. Standard-dose intravenous tissue-type plasminogen activator for stroke is better than low doses. Stroke 2014;45(8):2354-8.

21. Williams LS, Yilmaz EY, Lopez-Yunez AM. Retrospective assessment of initial stroke severity with the NIH stroke scale. Stroke 2000;31(4):858-62.

22. Sarikaya H, Arnold M, Engelter ST, et al. Outcome of intravenous thrombolysis in stroke patients weighing over $100 \mathrm{~kg}$. Cerebrovasc Dis 2011;32(3):201-6.

23. Nakashima T, Toyoda K, Koga M, et al. Arterial occlusion sites on magnetic resonance angiography influence the efficacy of intravenous low-dose $(0.6 \mathrm{mg} /$ $\mathrm{kg}$ ) alteplase therapy for ischaemic stroke. Int J Stroke 2009;4(6):425-31. 